\title{
Study of the speed of flame distribution in the combustion of methane-hydrogen fractions
}

\author{
$M A$ Taymarov $^{1}, R V$ Akhmetova $^{1, *}, Y e G$ Chiklyayev $^{1}, Y V$ Lavirko $^{2}, E A$ Akhmetov and $A O$ Garifullina \\ ${ }^{1}$ Russia, Kazan, Kazan State Power Engineering University, \\ ${ }^{2}$ Russia, Kazan, Kazan State University of Architecture and Engineering
}

\begin{abstract}
At present, natural gas of the Urengoyskoye field is burned in boilers of thermal power plants (TPP) to generate electricity. At the same time, refineries and petrochemical plants deepen the processing of fossil liquid hydrocarbons. The final product of processing is not only motor fuels, ethylene glycols, plastics, accompanying inert gases such as argon, but also a large amount of combustible secondary gaseous mixtures of the methane series. These mixtures contain a wide array of combustible components. Among them there is the methane-hydrogen fraction, which is characterized by a fairly high hydrogen content. A distinctive feature of the use of hydrogen as a fuel is the high rate of flame propagation and the relatively low heat of combustion [1, p.6-8]. The methane-hydrogen fraction due to the volatility of the composition and a wide range of changes in the heat of combustion was recently used in refineries for their own needs as an insignificant additive to combusted natural gas in process furnaces [2-5]. If the methane-hydrogen fraction was not utilized as a fuel in these furnaces, it was burned in flares. Due to the increase in oil refining volumes and the increase in the amount of methane-hydrogen fraction produced, it became realistic to use this gaseous fraction as the main fuel for power boilers of thermal power plants located near petrochemical plants. In the near future, it is planned to use the methane-hydrogen fraction as an additive to the natural gas for 20 power steam boilers of the Nizhnekamsk CHP-1 with a total thermal capacity of 6000 MW. The supplier of the methane-hydrogen fraction is the TAIF NK oil refineries. Depending on the technology of oil refining, the hydrogen content in the methane-hydrogen fraction ranges from 10 to $27 \%$ (by weight). The concentration limits of hydrogen ignition in a mixture with air have been experimentally studied by many researchers [6-8] mainly during bench testing or inside laboratories. A feature of the oxidation of hydrogen by air oxygen is the fact that there is a difference between the spread of the flame in limited volumes and in large volumes of the furnace space of energy boilers [9]. In small volumes, when the flame front collides with the wall, oxidation reactions are interrupted, and this does not occur in large volumes. Therefore, the study of flame propagation speed and concentration limits of ignition of methanehydrogen fractions mixed with air in relation to the conditions of furnace volumes of power boilers is relevant. In this work using the in-house software [2-5] calculations were made to determine the burning rate for various compositions of mixtures of methane-hydrogen fractions (MHF) with Urengoi natural gas. It was found that the flame propagation rate of the MHF, compared with hydrogen (see Table 2), decreases 1.76 times. For a mixture of the MHF with Urengoi gas with thermal fractions of the MHF of $12 \%$ and $25 \%$, the flame propagation rate increases, respectively, 1.4 times and 1.78 times compared with burning pure Urengoi gas.
\end{abstract}

\section{Introduction}

The role of the methane-hydrogen faction (MHF) in the TPP fuel balance is currently growing as a substitute of the natural gas. This can be connected to deepening of the oil refining process and an increase of the share of light refining products in the output of oil refining factories, where the amount of excess MHF products has grown accordingly. The peculiarity of hydrogen oxidization reactions lies in the fact that there is a difference in flame spreading in limited volumes and in large volumes of power boiler furnaces [9]. In the small volumes when the flame front collides with the wall, oxidation reactions are interrupted, and this does not occur in large volumes. Therefore, the study of flame propagation speed and concentration limits of ignition of methane-hydrogen fractions mixed with air in relation to the conditions of furnace volumes of power boilers is relevant.

\section{Description of an object and technique of a research}

Data on the composition of the methane-hydrogen fraction (MHF) are obtained from the results of the

* Corresponding author: ahmetova rv@bk.ru 
analysis of the "TAIF NK" chemical laboratory. Data on the composition of the combusted Urengoi gas is obtained from the results of the analysis of the chemical laboratory of the Nizhnekamsk CHP-1. The choice of the heat share of the MHF, equal to $12 \%$, in a mixture with combusted Urengoi gas is due to the design of the burners GMU-45 used in TGM-84B boilers. The heat share of the MHF of $25 \%$ in a mixture with Urengoi gas has been accepted as promising for burning in modernized burners of TGM-84B boilers. The calculation of the flame propagation speed and concentration limits of ignition was performed using the programs described in [2-5, 12-15].

In the Table 1 we list the composition of the methane-hydrogen fraction (MHF) in molar fractions in a mixture with Urengoi natural gas with a heat fraction in heat release of $12 \%$ and $25 \%$.

The $25 \%$ mixture presented in Table 1 is planned to be burned in the furnaces of the TGM-84B boilers at the Nizhnekamsk CHPP-1 starting June 1, 2019.

\section{The results of the study and their discussion}

Maximum speed $\mathrm{W}_{\mathrm{mn}}(\mathrm{cm} / \mathrm{s})$ of the flame front propagation of a mixture of MHF and Urengoi gas when ignited in air at atmospheric pressure and at a temperature of $0{ }^{\circ} \mathrm{C}$ was calculated using the following formula:

$$
\begin{aligned}
\mathrm{W}_{\mathrm{mn}}= & \left(\mathrm{m}_{1}\left|\mathrm{~W}_{\mathrm{mn} 1}+\mathrm{m}_{2}\right| \mathrm{W}_{\mathrm{mn} 2}+\ldots+\mathrm{m}_{\mathrm{i}} \mid \mathrm{W}_{\mathrm{mni}}\right) / \\
& /\left(\mathrm{m}_{1}+\mathrm{m}_{2}+\ldots+\mathrm{m}_{\mathrm{i}}\right)
\end{aligned}
$$

where $m_{i}$ is the mole fraction (\%) of the $\mathrm{i}$-th component; $\mathrm{W}_{\mathrm{mni}}$ is the maximum speed of flame propagation under normal conditions for the i-th component, $\mathrm{cm} / \mathrm{s}$.

The value $\mathrm{W}_{\mathrm{mn}}$ is understood as the speed of propagation of the flame front in the normal direction.
The concentration limit of ignition (in $\%$ ) of the mixture of MHF and Urengoi gas under normal conditions was calculated using the formula:

$$
\begin{gathered}
\mathrm{L}_{\mathrm{c}}=\left(\mathrm{m}_{1}+\mathrm{m}_{2}+\ldots+\mathrm{m}_{\mathrm{i}}\right) / \\
/\left(\mathrm{m}_{1} / \mathrm{L}_{1}+\mathrm{m}_{2} / \mathrm{L}_{2}+\ldots+\mathrm{m}_{\mathrm{i}} / \mathrm{L}_{\mathrm{i}}\right),
\end{gathered}
$$

where $\mathrm{L}_{\mathrm{ni}}$ and $\mathrm{L}_{\mathrm{vi}}$ are the lower and upper concentration limit of ignition of the i-th component, $\%$.

The values of the flame propagation velocity $(\mathrm{cm} / \mathrm{s})$ in air under normal conditions and the concentration limits of ignition (in \%) of the individual components are given in Table 2.

As can be seen from the Table 2, the hydrogen flame propagation rate is 7.2 times higher than that of methane, which makes up $98 \%$ of the Urengoy natural gas composition. The limits of hydrogen ignition, compared with methane, are much wider.

In the Table 3 we show the results of calculation of the maximum flame propagation velocity and the concentration limits for igniting the mixture of Urengoi gas with the MHF when burning in air under normal conditions for the MHF heat release fraction of 12 and $25 \%$.

As we can see from the Table 3 , the speed of flame propagation of the MHF, compared with hydrogen (see Table 2), decreases 1.76 times. For a mixture of the MHF with Urengoi gas with the heat fraction of the MHF of $12 \%$ and $25 \%$, the flame propagation rate increases, respectively, 1.4 times and 1.78 times compared with burning pure Urengoi gas.

To burn a mixture of Urengoi gas and the MHF with a $25 \%$ heat fraction of the MHF in TGM-84B boilers, modernized or special burners should be used, since due to the high propagation rate of the flames, the burning of the MHF in the horizontal gas duct of the TGM-84B boilers is inevitable. This will lead to an increase in the temperature of the combustion products in the horizontal gas duct, which, in turn, requires taking measures to

Table 1. Mole fraction (\%) of the components $\mathrm{m}_{\mathrm{i}}$ in the mixture of the MHF and Urengoi gas.

\begin{tabular}{|l|c|c|c|c|c|}
\hline \multicolumn{1}{|c|}{ Components } & Formula & \multicolumn{3}{c|}{$\mathbf{m}_{\mathbf{i}}$ mole fraction of components (\%) } \\
\hline & & MHF & Urengoi gas & $\begin{array}{c}\text { Mix with a heat } \\
\text { share of the MHF } \\
\mathbf{1 2} \%\end{array}$ & $\begin{array}{c}\text { Mix with a heat } \\
\text { share of the MHF } \\
\mathbf{2 5} \%\end{array}$ \\
\hline Hydrogen & & & 5.95 & 12.39 \\
\hline Methane & $\mathrm{H}_{2}$ & 49.57 & 0 & 90.64 & 81.75 \\
\hline Ethylene & $\mathrm{CH}_{4}$ & 30.48 & 98.84 & 0.007 & 0.015 \\
\hline Ethane & $\mathrm{C}_{2} \mathrm{H}_{4}$ & 0.06 & 0 & 1.87 & 3.79 \\
\hline Propylene & $\mathrm{C}_{2} \mathrm{H}_{6}$ & 14.88 & 0.1 & 0.0012 & 0.0025 \\
\hline Propane & $\mathrm{C}_{3} \mathrm{H}_{6}$ & $0 ., 01$ & 0 & 0.346 & 0.687 \\
\hline Butane & $\mathrm{C}_{3} \mathrm{H}_{8}$ & 2.66 & 0.03 & 0.14 & 0.265 \\
\hline Pentane & $\mathrm{C}_{4} \mathrm{H}_{10}$ & 1 & 0.02 & 0.009 & 0.0075 \\
\hline Hexane & $\mathrm{C}_{5} \mathrm{H}_{12}$ & 0 & 0.01 & 0.113 & 0.235 \\
\hline Nitrogen & $\mathrm{C}_{6} \mathrm{H}_{14}$ & 0.94 & 0 & 0.616 & 0.525 \\
\hline Carbon monoxide & $\mathrm{N}_{2}$ & 0 & 0.7 & 0.007 & 0.015 \\
\hline Carbon dioxide & $\mathrm{CO}$ & 0.06 & 0 & 0.28 & 0.25 \\
\hline Hydrogen sulphide & $\mathrm{CO}_{2}$ & 0.1 & 0.3 & 0.00032 & 0.00066 \\
\hline Water vapour & $\mathrm{H}_{2} \mathrm{~S}$ & 0.0026 & 0 & 0.029 & 0.06 \\
\hline
\end{tabular}


Table 2. Values of flame propagation velocity Wmni $(\mathrm{cm} / \mathrm{s})$ in air under normal conditions and concentration limits of ignition (in \%) of individual components [6-8].

\begin{tabular}{|l|c|c|c|c|}
\hline \multicolumn{1}{|c|}{ Components } & Formula & $\begin{array}{c}\text { Maximum speed of } \\
\text { flame propagation } \\
\mathbf{W}_{\mathbf{m n i}} \mathbf{\text { cm} / \mathbf { s }}\end{array}$ & \multicolumn{2}{c|}{$\begin{array}{c}\text { Concentration limit of ignition in air of } \\
\text { the i-th component,\% }\end{array}$} \\
\hline & & & lower $\mathbf{L}_{\mathbf{r i}}$ & lower $\mathbf{L}_{\mathbf{r i}}$ \\
\hline Hydrogen & $\mathrm{H}_{2}$ & 267 & 4 & 74.2 \\
\hline Methane & $\mathrm{CH}_{4}$ & 37 & 5 & 15 \\
\hline Ethylene & $\mathrm{C}_{2} \mathrm{H}_{4}$ & 63 & 3.75 & 29.6 \\
\hline Ethane & $\mathrm{C}_{2} \mathrm{H}_{6}$ & 40 & 3.22 & 12.45 \\
\hline Propylene & $\mathrm{C}_{3} \mathrm{H}_{6}$ & 44 & 2.4 & 10 \\
\hline Propane & $\mathrm{C}_{3} \mathrm{H}_{8}$ & 38 & 2.37 & 9.5 \\
\hline Butane & $\mathrm{C}_{4} \mathrm{H}_{10}$ & 37 & 1.86 & 8.41 \\
\hline Pentane & $\mathrm{C}_{5} \mathrm{H}_{12}$ & 38.5 & 1.4 & 7.8 \\
\hline Hexane & $\mathrm{C}_{6} \mathrm{H}_{14}$ & 38.5 & 1.25 & 6.9 \\
\hline Carbon monoxide & $\mathrm{CO}$ & 42 & 12.5 & 74.2 \\
\hline Hydrogen sulphide & $\mathrm{H}_{2} \mathrm{~S}$ & 50 & 4.3 & 45.5 \\
\hline
\end{tabular}

Table 3. The results of the calculation of the maximum flame propagation velocity and the concentration limits of ignition of the mixture of Urengoi gas with the MHF when burning in air under normal conditions for the heat release fraction of the MHF of 12 and $25 \%$.

\begin{tabular}{|c|c|c|c|c|c|}
\hline \multirow[t]{2}{*}{ Components } & \multirow[t]{2}{*}{ Formula } & \multicolumn{4}{|c|}{ Mole fraction mi (in\%) of the i-th component } \\
\hline & & MHF & Urengoi gas & $\begin{array}{c}\text { Mix with a heat } \\
\text { share of the MHF } \\
12 \%\end{array}$ & $\begin{array}{l}\text { Mix with a heat } \\
\text { share of the } \\
\text { MHF } 25 \%\end{array}$ \\
\hline Hydrogen & $\mathrm{H}_{2}$ & 49.57 & 0 & 5.948 & 12.393 \\
\hline Methane & $\mathrm{CH}_{4}$ & 30.48 & 98.84 & 90.637 & 81.75 \\
\hline Ethylene & $\mathrm{C}_{2} \mathrm{H}_{4}$ & 0.06 & 0 & 0.007 & 0.015 \\
\hline Ethane & $\mathrm{C}_{2} \mathrm{H}_{6}$ & 14.88 & 0,1 & 1.873 & 3.794 \\
\hline Propylene & $\mathrm{C}_{3} \mathrm{H}_{6}$ & 0.01 & 0 & 0.0012 & 0.0025 \\
\hline Propane & $\mathrm{C}_{3} \mathrm{H}_{8}$ & 2.66 & 0.03 & 0.346 & 0.687 \\
\hline Butane & $\mathrm{C}_{4} \mathrm{H}_{10}$ & 1 & 0.02 & 0.138 & 0.265 \\
\hline Pentane & $\mathrm{C}_{5} \mathrm{H}_{12}$ & 0 & 0.01 & 0.009 & 0.008 \\
\hline Hexane & $\mathrm{C}_{6} \mathrm{H}_{14}$ & 0.94 & 0 & 0.113 & 0.235 \\
\hline Nitrogen & $\mathrm{N}_{2}$ & 0 & 0.7 & 0.616 & 0.525 \\
\hline Carbon monoxide & $\mathrm{CO}$ & 0.06 & 0 & 0.007 & 0.015 \\
\hline Carbon dioxide & $\mathrm{CO}_{2}$ & 0.1 & 0.3 & 0.28 & 0.25 \\
\hline Hydrogen sulphide & $\mathrm{H}_{2} \mathrm{~S}$ & 0.00265 & 0 & 0.00032 & 0.00066 \\
\hline Water vapor & $\mathrm{H}_{2} \mathrm{O}$ & 0.24 & 0 & 0.03 & 0.06 \\
\hline \multicolumn{2}{|c|}{$\begin{array}{l}\text { Maximum speed of flame propagation, } \\
\mathrm{W}_{\mathrm{mn}}, \mathrm{cm} / \mathrm{s}\end{array}$} & 152 & 37 & 51 & 66 \\
\hline \multirow[t]{2}{*}{$\begin{array}{l}\text { Concentration limits } \\
\text { of ignition, } \%\end{array}$} & lower & 3.9 & $4, .992$ & 4.83 & 4.66 \\
\hline & upper & 22.48 & 14.99 & 15.62 & 16.36 \\
\hline
\end{tabular}

prevent overheating of the metal superheaters and, as a consequence, to a decrease in the efficiency of the boilers. The fact of increasing the temperature at the outlet of the furnace when the MHF is burned mixed with Urengoi gas is confirmed by an examination of the raw material heating furnaces at the vacuum gas oil hydrotreatment unit at Ryazan Refinery OJSC [1].

\section{Findings}

1. The speed of flame propagation of the MHF, compared with hydrogen (see Table 2), is reduced by 1.76 times due to the presence in the MHF of a large amount of methane.

2. On the TGM-84B type boilers, when burning an MHF mixture with Urengoi gas with an MHF thermal fraction of $12 \%$, burners of the GMU-45 type with 
central gas distribution and peripheral tangential air twist can be used.

3. When the MHF heat content is $25 \%$ in the mix with Urengoi gas, the flame propagation rate increases by 1.78 times compared to burning Urengoi gas, and development of modified burners with combined peripheral tubular and central gas distribution and axial twisting air is necessary.

\section{References}

1. M.A. Taimarov, N.E. Kuvshinov, R.G. Sungatullin, Yu.V. Lavirko, The reasons for the increase in temperature on the pass of the furnaces during the heating of vacuum gas oil, The Bulletin of Kazan Technological University, 19(20), 73-75 (2016)

2. M.A. Taimarov, R.V. Akhmetova, N.E. Kuvshinov, R.G. Sungatullin, Features of chemical reactions of combustion of methane-hydrogen fraction in radiant furnaces, News of universities. Energy problems. Kazan KGEU, 11-12, 124-128 (2016)

3. M.A. Taimarov, R.V. Akhmetova, R.G. Safin, Y.V. Lavirko, Calculation of Fuel Oil Drop Burnup Time Dependence on Intensity of Flame Radiation, Research Journal of Applied Sciences, 11(12), 1660-1665 (2016)

4. M.A. Taimarov, R.V. Akhmetova, E.A. Akhmetov, Efficiency of application of various layout arrangements of oil-gas burners in thermal power plant boilers, IOP Conference Series: Materials Science and Engineering, 552(1), 012008 (2019)

5. M.A. Taimarov, E.G. Chiklyaev, S.M. Margulis, Heat and burning intensity of a methane-hydrogen mixture depending on its composition. Technical systems and technological processes. Digest of articles, International Scientific and Practical Conference, 154-156 (2018)

6. J. Variatz, W. Maas, R. Double, Burning, 351 (2003)

7. G.D. Fernandez, F.L. Sanchez, One-step reduced kinetics for lean hydrogen-air deflagration, Combuust. Flame, 156, 985-996 (2009)

8. M.F. Ivanov, A.D. Kaverin, A.E. Smygalin, Ignition of the hydrogen-air mixture near the lower concentration limit, Bulletin MGTU them. N.E. Bauman. Series "Natural Sciences", 1, 89-108 (2013)

9. V.A. Gorev, About concentration limits of flame propagation in the system hydrogen-air, Fire and explosion safety of substances and materials, 12, 23$26(2011)$

10. R.V. Akhmetova, M.A. Taymarov, Ye.G. Chiklyayev, R.G. Sungatullin, Indicators of regime parameters of TGM-84B coppers when burning methane-hydrogen fraction in them, KSPEU bulletin, 1(33), 58-63 (2017)

11. K. Shimizu, A. Hibi, M. Koshi, Y. Morii, N. Tsuboi, Updated Kinetic Mechanism for High-Pressure Hydrogen Combustion, Journal of Propulsion and Power, 27(2), 383-395 (2011)

12. C.C. John, Transient radiative transfer in 2D cylindrical medium with collimated pulse irradiation, Journal of Quantitative spectroscopy and Radiative Transfer, 83, 299-313 (2004)

13. S.C. Mishra, P. Rath, Transient radiative heat transfer in participating media of Numerical heat transfer, Int. Journal of Heat and Mass transfer, 88, 746-752 (2008)

14. P.B. Abdallah, Thermal Emission of Semitransparent slab with variable spatial refractive index, Journal of Quantitative spectroscopy and Radiative transfer, 67, 185-198 (2000)

15. R.V. Akhmetova, M.A. Taimarov, E.A. Akhmetov, International Scientific and Practical Conference: Water Power Energy Forum 2018, IOP Conf. Series: Earth and Environmental Science, 288, 012075 (2019) 